

\section{Daftar Isi (Table of Content) Journal of Government
Civil Society}

\begin{tabular}{|c|c|}
\hline \multirow{3}{*}{$146-163$} & $\begin{array}{l}\text { New Public Management (New Public Comparison Meta-Analysis } \\
\text { Developed and Developing Country Policies) }\end{array}$ \\
\hline & Dyah Mutiarin $^{2}$, Misran ${ }^{1}$ \\
\hline & $\begin{array}{l}\text { (1 Department of Government Affairs and Administration, Universitas Muhammadiyah } \\
\text { Yogyakarta, Indonesia) } \\
\text { (2 Jusuf Kalla School of Government, Universitas Muhammadiyah Yogyakarta, Indonesia) }\end{array}$ \\
\hline \multirow{3}{*}{$164-183$} & $\begin{array}{l}\text { Policy Networks: Actors, Interests, and Power Relations in the Jakarta } \\
\text { Reclamation Project }\end{array}$ \\
\hline & Rizki Hegia Sampurna1,2, Chih-Chieh Chou ${ }^{1}$ \\
\hline & $\begin{array}{l}\text { (' Department of Political Science, National Cheng Kung University (NCKU), Taiwan) } \\
\text { ('2 Department of Public Administration, Universitas Muhammadiyah Sukabumi (UMMI), } \\
\text { Indonesia) }\end{array}$ \\
\hline \multirow{3}{*}{$184-197$} & $\begin{array}{l}\text { National Insights and Youth Political Attitudes in Rural Lampung Against } \\
\text { Negative Campaign }\end{array}$ \\
\hline & Hertanto $^{1}$, Handi Mulyaningsih ${ }^{2}$, Asep Nurjaman ${ }^{3}$ \\
\hline & $\begin{array}{l}\left({ }^{1} \text { Departement of Government Science, Universitas Lampung, Indonesia) }\right. \\
\left({ }^{2} \text { Departement of Sociology, Universitas Lampung, Indonesia) }\right. \\
\left({ }^{3} \text { Departement of Government Science, Universitas Muhammadiyah Malang, Indonesia) }\right.\end{array}$ \\
\hline \multirow{3}{*}{$198-213$} & $\begin{array}{l}\text { Ethnic Identity and Local Politics: Study on Regional Head Election in } \\
\text { Merauke Regency } 2020\end{array}$ \\
\hline & Misran', Wahdania Sardi' ${ }^{1}$, Zuly Qodir ${ }^{1}$ \\
\hline & $\begin{array}{l}\text { (1 Department of Government Affairs and Administration, Jusuf Kalla School of Government, } \\
\text { Universitas Muhammadiyah Yogyakarta, Indonesia) }\end{array}$ \\
\hline \multirow{3}{*}{$214-236$} & $\begin{array}{l}\text { Stakeholder Collaboration Model for Ecotourism Development: A Case } \\
\text { Study from Batu City, East Java Province }\end{array}$ \\
\hline & 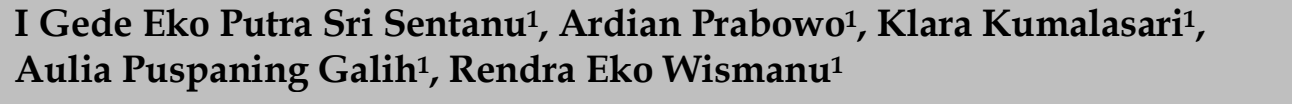 \\
\hline & (' Departement of Public Administration, Universitas Brawijaya, Indonesia) \\
\hline
\end{tabular}


Farmers Social Movement Studies: A Systematic Literature Review for A Conceptual Model

$237-262 \quad$ Wahyudi $^{1}$

(' Department of Sociology, Universitas Muhammadiyah Malang, Indonesia)

Factors Affecting Trust in E-Government

Ulung Pribadi' ${ }^{1}$, Muhammad Iqbal ${ }^{2}$, Fittia Restiane ${ }^{3}$

263 - 276 (1 Post-Graduate Program Universitas Muhammadiyah Yogyakarta, Indonesia)

( ${ }^{2}$ Department of Political Science National Cheng Kung University, Taiwan)

$\left({ }^{3}\right.$ Department of Government Affairs and Administration Universitas Muhammadiyah Yogyakarta, Indonesia) 


\title{
Policy Networks: Actors, Interests, and Power Relations in the Jakarta Reclamation Project
}

\author{
Rizki Hegia Sampurna ${ }^{1,2 *}$, Chih-Chieh Chou ${ }^{1}$ \\ ${ }^{1}$ Department of Political Science, National Cheng Kung University (NCKU), Taiwan \\ ${ }^{2}$ Department of Public Administration, Universitas Muhammadiyah Sukabumi (UMMI), Indonesia \\ *Email Correspondence: rizkicdn@gmail.com
}

\begin{abstract}
This case study seeks to understand the policy-making of the Jakarta bay reclamation project through the analytical lens of the policy networks. It posits that different policy networks would possibly produce or condition different policy outcomes in the project. The study uses a qualitative secondary data analysis. The study found: First, policy changes in the project, from initiation to implementation and finally termination, might be explained through the formation and transformation of different types of policy networks. Overall, the networks were characterized by fluctuating interactions among actors and the persistent power struggle between economic, environmental, and societal interests. Second, the networks' type changes were possible due to two factors: (1) the political context of the 2017 gubernatorial election; and (2) the influences of environmental and societal ideas.
\end{abstract}

Keywords: Issue networks, Jakarta bay reclamation, policy community, policy networks, power relations

\begin{abstract}
ABSTRAK
Studi kasus ini berupaya untuk memahami pembuatan kebijakan proyek reklamasi teluk Jakarta melalui lensa analitik policy networks. Studi ini berasumsi bahwa jenis policy networks yang berbeda mungkin akan menghasilkan atau mengkondisikan hasil kebijakan yang berbeda dalam proyek tersebut. Hasil studi ini menemukan beberapa temuan. Pertama, perubahan kebijakan dalam proyek, dari inisiasi hingga implementasi dan akhirnya penghentian, dapat dijelaskan melalui pembentukan dan transformasi berbagai jenis policy networks. Secara keseluruhan, networks tersebut ditandai oleh interaksi yang berfluktuasi di antara para aktor dan perebutan kekuasaan yang terus-menerus antara kepentingan ekonomi dan lingkungan dan masyarakat. Kedua, perubahan jenis networks tersebut kemungkinan disebabkan oleh dua faktor: (1) konteks politik Pilgub 2017; dan (2) pengaruh gerakan pemikiran lingkungan dan sosial.
\end{abstract}

Kata Kunci: Issue networks, policy community, policy networks, relasi kekuasaan, reklamasi Teluk Jakarta

\section{INTRODUCTION}

The Jakarta Bay reclamation project continues to be a contested policy issue in Indonesia. It covers an extended period, going through different political administrations, from the Soeharto administration to the current one of Jokowi. It began in 1995 when President Soeharto issued Presidential Decree No. 52 of 1995 on the project's initiation (PT. Kapuk Naga Indah 2012, pp. 1-2; Himawan, 2016). And since then, there have been many different, even conflicting, policies or regulations issued by other government institutions

Citation : Sampurna, R. H., \& Chou, C.-C. (2021). Policy Networks: Actors, Interests, and Power Relations in the Jakarta Reclamation Project. Journal of Government and Civil Society, 5(2), 164-183. https:/ / doi.org/10.31000/jgcs.v5i2.4132 
(Velarosdela, 2018). In addition, due to its multidimensional nature, the project also involves diverse actors from a wide range of sectors; government, private and societal actors who belong to the economic and urban planning sector to that of environment and fishery (LembagaBantuanHukum Jakarta, 2019; hereafter LBH).

As such, it is not surprising that it continues to attract much attention from the public and academia. Accordingly, such a complex and multifaceted issue invites scholars from a wide range of disciplines to offer insightful explanations and understanding about it. Until recently, studies mainly focused their analyses on a thorough examination or assessment of the project's impacts, negative or positive, or cost and benefit. They mostly come from disciplines such as Civil Engineering, Environmental Studies, Fisheries, and Marine Sciences, and so on (Arsyad, 2008; Rudianto, 2014; Supartono et al., 2015; Ramadhan et al., 2016; Irianto et al., 2017; Colven, 2017; Salim et al., 2019).

Nevertheless, a few policy studies offer insights into the complexity of the policymaking process of the Jakarta reclamation project. These studies mainly focus their analysis on two themes. First, the overlapping and contradictory regulations of the project among different departments, of either the Central Government or Provincial Government of Jakarta (Mutia and Asteria, 2008; Karim n.d.). Second, conflicting economic and political interests among government and other actors underpin the power struggle in the reclamation project (Mutia and Asteria 2008; Mahdi 2017; Rahmawati and Firman 2019; Adharani et al. 2019). We argue that the concept of policy networks would offer alternative insights about the issue and thus enrich and further expand the extant policy discourses.

In that relation, the study seeks to explain the policy outcomes of the Jakarta reclamation project as an empirical case through the analytical lens of the policy networks. To that end, the study attempts to (1) identify the type of policy networks, and their changes; (2) analyze the effect of different types of the policy networks on the reclamation policy; (3) explore what constitutes changes in the policy networks.

\section{LITERATURE REVIEW}

\section{Policy Networks}

The concept of policy networks continues to develop along with its diverse epistemologies, methodologies, and approaches. The earlier conception of policy networks developed by Marsh and Rhodes and Smith was understood as a model of interest group representation (Marsh, 1998, p. 5-7). Supporting that view, Daugbjerg and Marsh (1998) argue that policy networks "are crucial political structures through which we are governed or ruled (p. 55)." Following a typical political analysis of "who gets what and how," Rhodes unequivocally states that policy networks talk about the actors, the interests they pursue, and the way or mechanism of the policy formulation and implementation (Rhodes, 1997, p. 10). 
Another group of scholars focuses on the patterns of governance. For instance, Klijn, Koppenjan, and Termeer (1995, p. 439) characterized policy networks as patterns of relationships between interdependence actors involved in processes of public policymaking. To them, the concept centered on interdependence as a keyword in the network approach. They argue that as a game about policy-making, the effects of policy networks lie in the effective management of the network (p. 441-443). As Rhodes (2007) argues that the essence of policy networks is "Institutional linkages between governmental and other actors structured around shared interests in public policy making and implementation (p. 2)." This earlier band of heavily British-minded scholars treated the policy networks as a form of governance that focused their analysis on institutional linkages between government and other actors. Or later on, known as the structural approach.

Later scholars shift the approach from structural to more societal orientation and public participation. For instance, Coleman and Skogstad focused on those actors excluded from and critical to the exclusive policy-making circles (Skogstad, 2005, p. 3). Similarly, Laumann\&Knoke (cited in Yi \&Scholz, 2016, p. 254) view policy networks as a set of actors with significant concern about a substantive area, whose preferences and actions on policy events must be taken into account by the other domain participants. Börzel advances the approach by bringing more analytical functions to it by specifying the policy networks into interest intermediation or governance (Börzel, 2002, p. 255-258; Bevir and Richards, 2009, p. 4). This band of scholars views the policy networks as a typology of interest intermediation rather than a form of governance (Richardson, 2000).

More importantly, there has been inconclusive debate about the analytical utility of the policy networks. As a model, it has been under severe criticism for its lack of analytical function. Policy scholars have attempted to better operationalize the model through different approaches (Marsh, 1998, p. 185-190). Marsh and Rhodes' structural approach, for instance, has been known for three characteristics. First, it is essentially structural and downplays the importance of agents. Second, the structure of the network affects policy outcomes. Third, it suggests that exogenous factors affect the change in both policy networks and policy outcomes. The underlying assumption is that the driving force of change in the network and the effect lies in broader economic and political instability and differences in knowledge.

In contrast, Dowding (1995) criticizes the structural model as failing to collect sufficient detail about the interactions within the networks. Proposing a rational approach, he argues that resource exchange among agents within the networks affects the outcomes. Therefore, for Dowding, such a model might rather be considered a metaphor (Dowding, 1995, p. 137-138). In response, Marsh and Smith (2001, p. 535-538) later developed a more comprehensive model, paying attention to structure and agent and capturing the iterative interaction between policy networks and outcomes, which they called a dialectical model. In essence, these approaches posit that both network structure, agency, and their 
interactions relatively significantly affect the policy outcome. In sum, as Marsh and Smith (2000) declare, policy networks refer to the fact that relatively small groups make a great deal of policy of closely linked actors.

\section{Classifying Policy Networks: Policy Community and Issue Networks}

Marsh and Rhodes (1992) developed a generic classificatory scheme of policy networks as a continuum that distinguishes policy community and issue network. There are four dimensions along which networks vary; interest, membership, interdependence (vertical and horizontal), and resources. But the empirical investigation is concerned with the degree to which anyone or set of characteristics is present (Marsh and Rhodes, 1992, p. 250-252). Both policy community and issue networks are seen as types of relationships between interest groups and government. Networks can vary along a continuum according to the closeness of the relationship within them. The policy community is at one end of the continuum consisting of stable, exclusive and close networks; while issue networks are at the other end, composed of multiple, inclusive, or loosely networks (Rhodes, 1997, p. 44-45).

Furthermore, Peterson (2003, p. 4) simplified the model by focusing on three key dimensions to determine policy networks in a specific sector. First, the relative stability of a network's membership. It concerns whether the same actors tend to dominate decisionmaking over time or is membership fluid and dependent on the specific policy issue under discussion. Second, the network's relative insularity. It concerns whether it is a conspiracy that excludes outsiders or is it highly permeable by a variety of actors with different objectives or not. Third, the strength of resource dependencies. It concerns whether network members depend heavily on each other for valued resources such as money, expertise, and legitimacy. Are most actors self-sufficient and thus relatively independent of one another?

Notwithstanding criticism from many scholars about the risk of oversimplification, the network's typology has a relatively demonstrated explanatory function on the policy outcomes (Marsh and Rhodes, 1992, p. 250). We assume that networks, as Atkinson and Coleman (1992) argue, "are governed by sets of rules which determine how decisions are made and who participates in policy making (p. 172)." A similar position taken by Marsh and Smith (2000, p. 4) argues that policy networks as the structure can determine the roles actors play within the networks and choose an issue over others as an agendasetting stage in the policy-making process. Accordingly, many researchers used this typology as either an independent or intervening variable in their studies to analyze policy outcomes at a given policy issue or sector. For instance, adopting Peterson's approach, Bomberg (1998, p. 167-184) examined different effects in European environmental policy caused by the issue networks. 


\section{Theoretical Propositions}

Drawing mainly on the literature, we argue that we could explain policy outcomes of the Jakarta reclamation project by using the policy networks as an analytical lens. As such, the study posits the following theoretical propositions to examine the Jakarta reclamation case empirically at hand: (1) Relative stability of networks' membership, relative insularity, and strength of resource dependency together would affect formation and transformation of policy networks; (2) The formation and transformation of policy networks would likely affect policy outcomes of the reclamation project; (3) In sum, it argues that changes in the type of policy networks as are embedded in its three dimensions would likely produce policy changes in the reclamation project. The propositions are illustrated as follows:

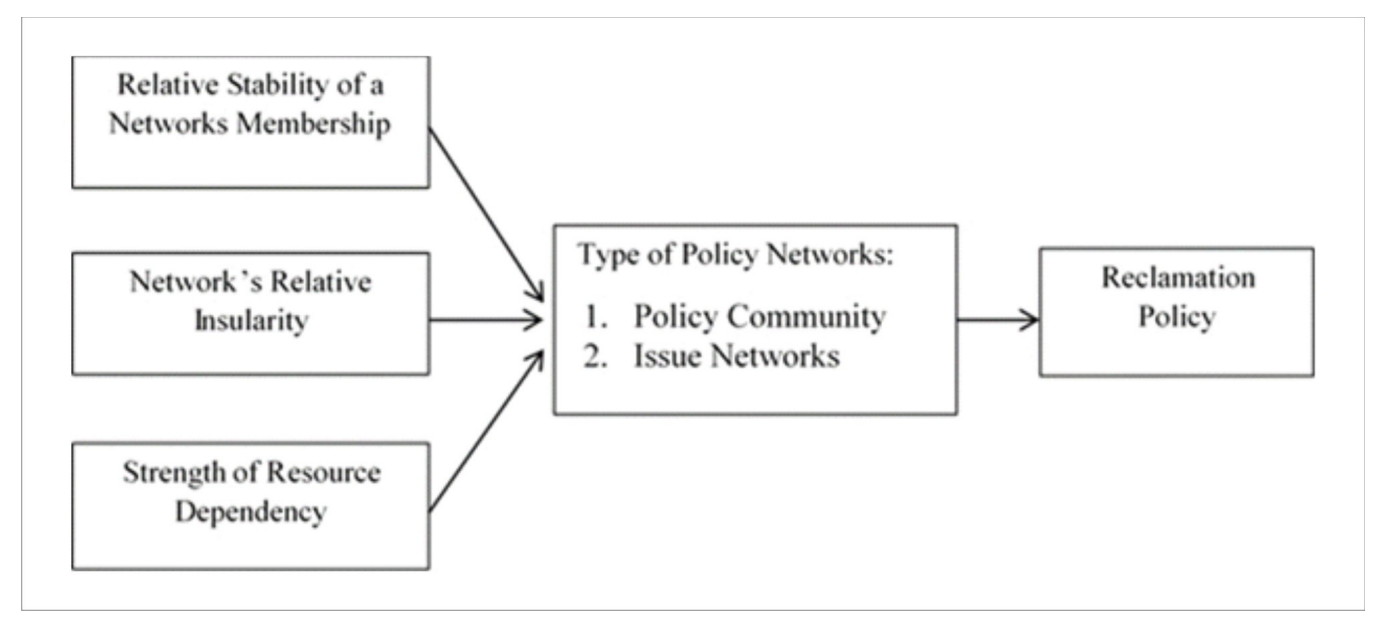

Figure 1. Theoretical Propositions

Source: Compiled from different sources

\section{RESEARCH METHOD}

The debates in the study of policy networks also centered on the methodological distinction between qualitative and quantitative analyses (Börzel, 2002, p. 255). As the study aims at both explaining the uniqueness of the case and generalizing its analytical themes in terms of policy networks, it accordingly follows a kind of crucial single case study (George and Bennett, 2005, p. 101-102; Yin in Bickman and Rog, 2009, p. 256-257; Yin, 2018). Practically, this case study uses a qualitative secondary data analysis. It uses the extant qualitative reports, mainly in text data, and re-analyzes them through the policy networks' perspectives.

The study uses and analyses secondary data collected mainly from online newspapers, relevant organizations' websites, previous studies, and other sources in the following forms (Hakim, 2000, p. 24-25). First, official documents from government and non- 
government organizations include laws, regulations, decrees, statement declarations, etc. Second, media-based data such as news items, talk shows, dialogue, and debates are covered by print and electronic (Elliott and Squire, 2017). We focus on the reports or news items covering the pre-and post- periods of the 2017 gubernatorial election, from 2015 to 2019. We present the data in a historical or chronological narrative and then interpret them with reference to the extant studies, particularly in light of theories of policy networks (George and Bennett, 2005, p. 157-159; Yin, 2018). By that, we could reach a fresh understanding of the case. To ensure the validity of its findings, the study adheres to strict methodic-ness, seeks multiple sources of data, and looks for counterexamples (Yin, 2011, p. 78-82).

\section{RESULTS AND DISCUSSION}

\section{The Long Road of Reclamation Policy: An Endless Power Struggle}

We could identify three periods of the Jakarta reclamation policy. This periodization is based on two criteria. First, it is based on policy outcomes to either implement the reclamation project or stop it. Second, it is based on the relative significance of policy sectors. For instance, at a particular point in time, the reclamation was put under the command of the environmental industry. Resultantly, those actors in this sector, such as the Ministry of Environment and Ministry of Marine and Fishery, got more political leverage. While at the other period, it was considered under the domain of urban development and planning. The actors from this sector, such as the Provincial Government, developer companies, the National Board of Urban Planning and Development, might gain a more decisive role.

The first period of reclamation policy began from its initiation in 1995 to 2003. To implement Presidential Decree No. 52/1995 and Provincial Regulation No. 8/1995, the reclamation project was initially implemented through a joint project by Provincial Government and developer company Kapuk Naga Indah Ltd. In 2003, the Ministry of Environment and Forestry took a decisive role by stating that the reclamation was not feasible and had to stop through Ministerial Decree No. 14/ 2003 (Himawan, 2016; Setiaji, 2019). So, the reclamation policy changed. The main actors during this period were mainly the Ministry of Environment and Forestry, the Provincial Government, and the Developer Company.

The second period started from 2007 to 2016. This period began with the companies' decision to sue the Ministry of Environment in 2007. It ended with the decision to Coordinating the Ministry of Maritime Affairs to resume implementing the reclamation project in 2016. During this period, the policy outcome was to continue the implementation of the project. Except for a brief interval in 2016 when a joint committee chaired by the 
Coordinating Ministry of Maritime Affairs consisted of the Ministry of Environment, Ministry of Marine and Fishery, and Provincial Government issued the decree to temporarily halt the project (KemaritimandanInvestasi, 2016a; Simbolon, 2016). Mostly upheld explanations behind this brief policy change are twofold: Firstly, the then Minister of Maritime Affairs, Rizal Ramli, has been well known for his strong leadership, the outspoken activist and somehow pro- environmentalist agenda; and secondly, resultantly the civil societies and fishery communities had more chance to have their voices taken into account in the policy making process.

The Minister admitted that the reclamation project had potential floods (KemaritimandanInvestasi, 2016b). The Minister also showed his political will to listen to public concerns such as Jakarta Bay Fishermen or fishery communities (Kemaritimandaninvestasi, 2016c). Moreover, the Ministry of Environment insisted that this reclamation project did not fully comply with the Environmental Impact Assessment (EIA) requirement and thus needed re-evaluation (Gabrillin, 2016). But the tide changed when Luhut Binsar Pandjaitan took over the post of Coordinating Ministry of Maritime Affairs. The moratorium was revoked, and the project was once again given a go-ahead instruction (Fadhilah, 2016; Harahap, 2016). During this period, the policy-making involved more diverse actors and more dynamic political interactions.

The third period started from 2017 to the moment the newly elected Governor eventually stopped the project in 2018. It dated back to the 2017 gubernatorial election, during which the contending candidate, AniesBaswedan, made a commitment to halt the project if he got elected. During the campaign, he took a side with civil societies such as the Indonesian Forum for the Environment (WahanaLingkunganHidup Indonesia/ WALHI), People's Coalition for Fisheries Justice (Koalisi Rakyat untukKeadilanPerikanan/ KIARA), Indonesian Center for Environment Law (ICEL), and some others who often worked together under the platform of KoalisiSelamatkanTeluk Jakarta (KSTJ/ Save the Jakarta Bay Coalition). On many occasions, he unequivocally refused to continue the reclamation project as it brought about environmental damages and negative impacts to coastal and fishery communities (Fadhil, 2016; Pratiwi, 2017; Putera, 2017). As he got elected in 2018, he abolished the extent of problematic regulations and issued Governor Decree No 58/2018 to form a kind Reclamation Management Board (BKP) to re-evaluate the reclamation project thoroughly.

As such, the Governor meant to restructure the networks and demonstrate his authoritative position on it (Agung, 2018a; Nailufar, 2018). The policy was also intended to materialize the Governor's campaign promise to accommodate the environmental agenda and societal interests. But the policy was again severely criticized by civil societies as a half-hearted alignment to the environmental plan and the interests of the Jakarta fishing communities. For instance, KSTJ even decided to continue the project rather than stop it (Damarjati, 2018). The Governor responded that such a decree was a must-to-do 
step to stop the reclamation (Azhar, 2018) legally. Experts agreed that such a decree was indeed a necessary initial step to resolve the timely complicated reclamation issue (Agung, 2018b). After a few months of investigation, validation, and verification processes, the board recommended the Governor to put the project to a halt. By the end of 2018, the new Governor formally sealed the reclamation project, symbolizing policy change in the long journey of Jakarta bay reclamation (Pradewo, 2018; Sari, 2018).

Using the analytical lens of policy networks, we could see that all these twists and turns in the Jakarta reclamation project reflect the underpinnings power relations of the networks. The very concept of policy networks captures this kind of power relationship between the actors in the policy-making arena (Skogstad, 2005, p. 3). Even Atkinson, Coleman, and Skogstad further classified different types of power relationships between state and non-state actors such as "state-directed networks, clientele pluralist networks, corporatist networks (cited in Skogstad, 2005, p. 4)." In this case, the power relationships were seen as blatant conflicting interests between actors in the economic camp and those in the environmental and societal one (Mutia and Asteria, 2008, p. 5). Studies even posit that the political economy aspects of the reclamation project have attracted much public attention than its pure economic or environmental one (Mahdi 2017, p. 41-43). This power relationship demonstrated masculine or patriarchal power syndrome and thus unfriendly to the environment, local communities, families, and women aspirations (Rahmawati and Firman, 2019, p. 57-59).

The power struggle was further fueled by overlapping and sometimes contradictory laws and regulations (Mutia and Asteria, 2008, p. 4; Karim n.d., p. 3). For instance, some limitations give different authorities to different institutions on the reclamation policy such as Presidential Decree No. 52/1995 and No. 122/2012 on Reclamation in Coastal Areas and Small Islands, Government Regulation No. 5/2010 on Navigating, Law No. 23/2014 on Local Government, and so on (Mutia and Asteria, 2008, p. 5). Thus, by stopping the project, the Governor indeed rebalanced the power of the extant reclamation regime and changed the very nature of the established policy networks (Henaldi, 2018). Borrowing Marsh' word, the Governor is an agent who ultimately "...bargain, conflict and break up networks (Marsh and Rhodes, 1992, p. 195)."

\section{Explaining the Reclamation Policy Outcomes through the Policy Networks}

The above results shed light on some critical points. First, the policy formation of Jakarta's reclamation is vertically multilayer and horizontally complex. Vertically, it involves different Government institutions such as Ministries and agencies of the Provincial Government of Jakarta. Horizontally, it involves diverse actors from other sectors and policy agendas, ranging from government institutions, developer companies, civil societies, media, and even academia. Applying Peterson's approach is therefore helpful because it 
helps explain the varying strength of different actors in different policy sectors and agendas. Its emphasis on resource dependencies helps identify which actors have a more decisive role in the policy formulation and implementation and further explain why. Second, the long on/off policy indicates that actors cannot exercise a firm and stable policy position in an extended period. Third, the reclamation policy is characterized by continuing, even sometimes rapid changes and fierce power struggles between two actors' camps. Thus, the networks were unstable.

Furthermore, drawing on Peterson's approach, we might explain the formation and transformation of the policy networks across different project periods. First, in terms of the relative stability of a network's membership, it is argued that the Provincial Government (the Governor) and developer companies had been the dominant actors in the reclamation policy during the first period. Until finally, in 2003, the Ministry of Environment rebalanced the power structure and took a decisive role by arbitrarily declaring it as not feasible and had to stop. But the point is it was a tight interaction and involved very limited actors. There were only three actors directly involved, and the rest were by and large excluded from the policy-making process.

While more diverse actors got involved in the policy-making process in the second period, the dominant actors were relatively still the same and limited. Especially those actors who champion economic agenda such as the Ministry of Maritime Affairs, Provincial Government and developer companies, had a more decisive role in the critical phase of policy formulation and implementation. Those environmental and societal champions gained a more significant role in the last period by forming a joint strategic pact with the newly elected governor. By issuing Governor Decree No 58/2018, the newly elected Governor changed the network structure into a loosely network with multi actors who could put influences into policy formulation. The Coordinating Ministry of Maritime, Ministry of Environment, Governor, and developer companies were not the only actors who had a decisive say. Civil societies such as WALHI, LBH, KNTI, and others also exercise public control over government policy.

Second, in terms of the network's relative insularity, it is argued that in the first and second periods, the insularity was highly exclusionary. Many actors, mainly from civil societies and other less relevant institutions were not adequately considered board. Their positions were primarily at the periphery of policy networks. Even if they exercised their power, they were overpowered, and more authoritative and influential actors stepped aside. The Ministry of Marine Affairs and Fisheries and Ministry of Environment and Forestry, for instance, had been consistently critical of the environmental impact of the reclamation project (Andinni, 2016; Hidayat, 2016; Tim, 2018). While in the last period, it was more permeable, wherein many diverse actors with different interests had relatively equal access to the policy process. Through the 2017 gubernatorial election, those actors 
who had been critical to the reclamation project could channel their agenda. And finally, got due roles to advocate their different interests.

Third, the strength of resource dependencies might answer why a particular actor was more dominant than the others. It is argued that in the first and second periods, the economic interests of developer companies were dominant due to an asymmetric resources exchange between them and government institutions; Provincial Government, and Ministries. The companies' resources are mainly financial resources, technical or technological expertise of reclamation projects, legal standing, and the government ambition to generate more incomes by establishing new business hubs, urban development, coastal recreation, and so on. At the same time, the companies' alliance with the government was also entirely independent from civil societies. During this period, the interaction was very tight in that civil societies, let alone the public, were hardly able to access the policymaking process. The relationship was asymmetric in terms of resource dependencies.

Meanwhile, the new Governor, Ministry of Environment, Ministry of Marine and Fishery, and civil societies gained a significant role in the last period. He was able to rebalance the resources of companies and coordinate the Ministry of Maritime Affairs. Their resources were in the form of legitimacy and intellectual expertise, primarily in critical studies or thoughtful opinions from academia. In this regard, think tanks such as the Coalition of Inter-disciplinary Experts (KoalisiPakarInterdisiplin) played a role by diffusing objective information, forming public opinion, and thus promoting knowledgebased policy. The reclamation policy was one of the demarcating platforms between the contending candidate who sided with civil societies and the incumbent who sided with the companies and those actors from the economic camp (Kompas.com TV, 2016; Metrotvnews, 2017). Accordingly, when the contender won the election, it was interpreted as a public mandate to terminate the reclamation project (CNN Indonesia, 2018).

The newly elected Governor and his strategic allies from the environmental and societal camp gained more political leverages to directly challenged the Minister of Maritime Affairs (Ambari, 2017; Redaksi, 2017). Initially, the Minister and companies threatened to sue the new Governor if he dared to revoke the permits (Kuwado, 2017). But the Governor did not bow to their threat (Metrotvnews, 2018). In sum, the interactions pattern during this period was fluid, loosely, and based on relatively similar resource dependencies. The actors' composition and position of different networks types in the Jakarta reclamation policy can be seen in the following table: 
Table 1. Actors Composition and Position in Jakarta Bay Reclamation

\begin{tabular}{|c|c|c|c|}
\hline Policy & & Actors & \\
\hline $\begin{array}{l}\text { Urban } \\
\text { Planning \& } \\
\text { Development }\end{array}$ & $\begin{array}{l}\text { Period I (1995- } \\
\text { 2003) } \\
\text { Provincial } \\
\text { Government } \\
\text { (Governor), } \\
\text { Developer } \\
\text { Companies }\end{array}$ & $\begin{array}{l}\text { Period II (2007-2017) } \\
\text { Coordinating Ministry } \\
\text { of Maritime Affairs, } \\
\text { Provincial } \\
\text { Government } \\
\text { (Governor), Developer } \\
\text { Companies }\end{array}$ & $\begin{array}{l}\text { Period III (2018) } \\
\text { Coordinating Ministry } \\
\text { of Maritime Affairs, } \\
\text { Provincial Government } \\
\text { (Governer), Developer } \\
\text { Companies }\end{array}$ \\
\hline Environment & $\begin{array}{l}\text { Ministry of } \\
\text { Environment } \\
\text { and Forestry }\end{array}$ & $\begin{array}{l}\text { Ministry of Marine } \\
\text { Affairs and Fisheries, } \\
\text { Ministry of } \\
\text { Environment and } \\
\text { Forestry, Provincial } \\
\text { Government } \\
\text { (Governor) }\end{array}$ & $\begin{array}{l}\text { Ministry of Marine } \\
\text { Affairs and Fisheries, } \\
\text { Ministry of } \\
\text { Environment and } \\
\text { Forestry, Provincial } \\
\text { Government } \\
\text { (Governor), Civil } \\
\text { Societies (KNTI, } \\
\text { WALHI, ICEL, LBH } \\
\text { Jakarta, etc.) }\end{array}$ \\
\hline $\begin{array}{l}\text { Policy Change } \\
\text { (Outcomes) }\end{array}$ & $\begin{array}{l}\text { Initiation -> } \\
\text { Stop }\end{array}$ & $\begin{array}{l}\text { Implementation (brief } \\
\text { moratorium in 2016) }\end{array}$ & Permanent Stop \\
\hline $\begin{array}{l}\text { Type of Policy } \\
\text { Networks }\end{array}$ & $\begin{array}{l}\text { Policy } \\
\text { Community }\end{array}$ & Policy Community & Issue Networks \\
\hline $\begin{array}{l}\text { Dominant } \\
\text { Interest }\end{array}$ & $\begin{array}{l}\text { Economic -> } \\
\text { Environment }\end{array}$ & Economic & $\begin{array}{l}\text { Environment and } \\
\text { Societal }\end{array}$ \\
\hline
\end{tabular}

Source: Proposed by authors based on data analysis

Is it not too heuristic to conclude such networks types and make them fit into the policy changes or outcomes? Apart from Peterson's analytical lens above, we could comprehend the network's changes and policy changes in the Jakarta reclamation project from the following evidence. First, changes in compositions and boundaries of the networks. As Atkinson and Coleman (1992, p. 172) argue, the inclusion of new actors into the network or their changing positions from relatively peripheral positions to the core ones would indicate changes of the policy networks. This is particularly true regarding the 
"attentive public" who were previously excluded from the networks. It is evident from the table above that in the second period, the networks were dominated by actors who primarily pursued economic interests. At the same time, those actors who advocate the environmental and societal interests were either in peripheral positions such as the Ministry of Marine Affairs and Fisheries, Ministry of Environment and Forestry, or being excluded from the networks at all such civil societies WALHI, KNTI, LBH, etc. Contrastingly, in the third period, those "'attentive public" could join the networks or exert more influence on the policy-making agenda.

Second and most evidently, the changes in terms of resources and interests. Perhaps the most important indicators of any policy changes are interests (Skogstad, 2005, p. 8). The demarcating characteristic between different types of policy networks is policy interest. Economic interests of big corporates dominated the policy agenda in the first and second periods; while in the third one, the environmental and societal plan were able to rebalance the power structure of the networks. It is also true in terms of resources. Technological and technical expertise, which companies previously monopolized, become dispersed relatively equally among many actors within the networks and without. The actors' position and interactions of the issue networks that took place in the third period of the Jakarta reclamation policy might be better illustrated in the following figure:

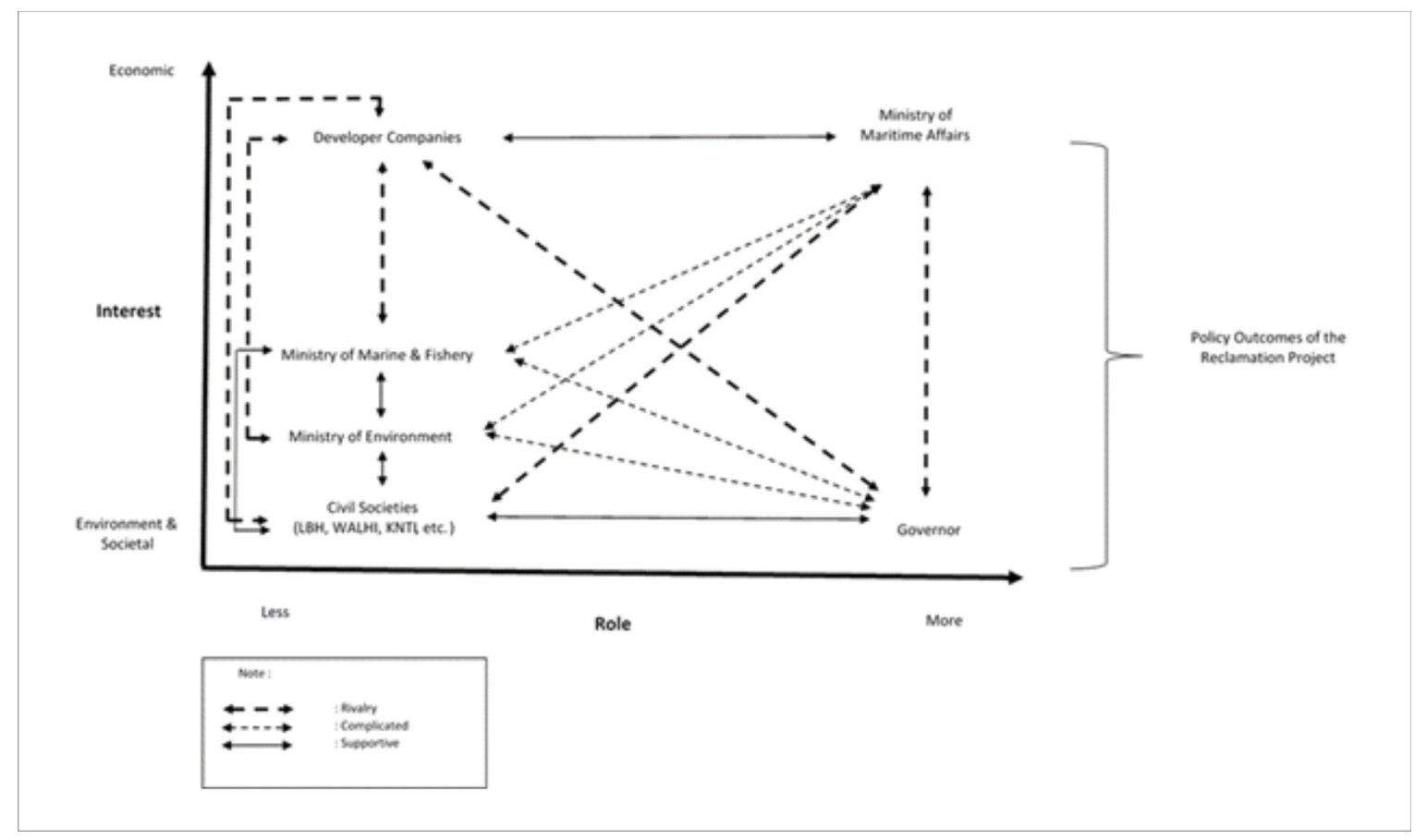

Figure 2. Actors' Position and Interactions of the Issue Networks Source: Proposed by Authors based on Data Analysis 
The figure demonstrates two differentiating dimensions in identifying actors' position and interactions in the issue networks of the Jakarta reclamation project. The actors were positioned according to either economic or environmental and societal welfare policy interests on the Y-axis. The preceding discussion shows us that civil societies, the Ministry of Environment and Forestry, the Ministry of Marine and Fishery, and the Governor of Jakarta were positioned as pro-environment and societal interest. In contrast, developer companies and the Ministry of Maritime Affairs were set as champions of economic interest. But a more interesting discussion is on interactions among actors. Since civil societies and the Governor were on the environment and societal welfare, their relations with developer companies and the Ministry of Maritime affairs must be logically rivalry. And vice versa. But it is not the case with the Ministry of Environment and Forestry and Ministry of Marine and Fishery. Although they were based on the environment and societal interest, their relations to developer companies and the Ministry of Maritime Affairs were quite different. While they took a rivalry stance toward developer companies, they seem uncritical and powerless against the Ministry of Maritime Affairs, which strongly advocated the economic interest. At the same time, notwithstanding their support for civil societies, they kept a distance from the Governor. On the X-axis, it is evident that the Governor and Ministry of Maritime Affairs had a more decisive role in the policy-making process of the reclamation project.

\section{CONCLUSION}

We might argue that the model of policy networks by Marsh and Rhodes is helpful to explain this empirical case. It helps us comprehend the actors, interests and power relations in the very complex policy making of the Jakarta reclamation project. Moreover, the model also serves to analyze the context and conditions of policy changes across different periods of the reclamation project as follows. First, policy changes in the project might be explained through the formation and transformation of different types of policy networks. The policy change from implementation to stop in the first period I (1995-2003) was conditioned by formation of the policy community. Whilst, brief policy changes in the second period (2003-2017) were conditioned by transformation from the policy community with relatively small number of actors to that one with more actors. And finally, the termination of the project in 2018 was conditioned by formation of the issue networks. Overall, the network was consistently characterized by fluctuating interactions among actors and persistent power struggle between economic and environment and societal interests. Second, the changes in the types of policy networks were possibly due to two factors: (1) political context of 2017 gubernatorial election and new political legitimacy of Provincial Government; (2) ideational factors in that the environmental and societal ideas penetrated public discourses and were able to exert influences into the policy formulation and implementation. 


\section{REFERENCES}

Agung, Bintoro. (2018, June 13). Beda VisiAhokdanAniessoalReklamasiTeluk Jakarta. CNN Indonesia. https:/ / www.cnnindonesia.com/nasional/20180613173851-20305939/ beda-visi-ahok-dan-anies-soal-reklamasi-teluk-jakarta

Agung, Bintoro. (2018, June 1). Pengamat: FungsiPergubAniesuntukRancangPerdaReklamasi. CNN Indonesia. https:// www.cnnindonesia.com/nasional/20180614153040-20-306107/pengamat-fungsipergub-anies-untuk-rancang-perda-reklamasi

Andinni, AlfaniRoosy. (2016, April 13). Menteri Susi dan DPR SepakatHentikanReklamasi Jakarta. CNN Indonesia. https://www.cnnindonesia.com/nasional/2016041320445120-123794/menteri-susi-dan-dpr-sepakat-hentikan-reklamasi-jakarta

Ambari, M. (2017, May 8). PemerintahLanggarHukumLagidalamProyekReklamasiTeluk Jakarta? Mongabay. https://www.mongabay.co.id/2017/05/08/pemerintahlanggar-hukum-lagi-dalam-proyek-reklamasi-teluk-jakarta/

Arsyad, A. (2008). Coastal Reclamation Projects in Indonesia: The Weaknesses Which Lead to Severe Socio-Environmental Impacts. Proceedings International Conference on Environmental Research and Technology, UniversitiSains Malaysia, 426-429. https:/ / www.semanticscholar.org/paper/Coastal-reclamation-projects-inIndonesia\%3A-the-lead-Arsyad/7669ee472bbdeee642aacf16cc80e4c3d31e99f

Atkinson, Michael M. \& Coleman, William D. (1992). Policy Networks, Policy Communities and the Problems of Governance. Governance 5 (2), 154-180. https:/ / doi.org/10.1111/j.1468-0491.1992.tb00034.x

Azhar, M Sholahadhin. (2018, June 15). Anies: JanganBerimajinasiSoalReklamasi. Medcom.id. https://www.medcom.id/nasional/metro/nbw7Pd3b-anies-janganberimajinasi-soal-reklamasi

Bevir, Mark \& Richards, David. (2009). Decentring Policy Networks: A Theoretical Agenda. Public Administration 87 (1), 3-14 https://doi.org/10.1111/j.1467-9299.2008.01736.x Bomberg, Elizabeth. (1998). Issue Networks and the Environment: Explaining European Union Environmental Policy. In David Marsh (Eds.), Comparing Policy Network, (pp. 167-184) Open University Press.

Börzel, Tanja. A. (2002). Organizing Babylon: On the different conceptions of policy networks. Public administration 76 (2), 253-273. https://doi.org/10.1111/14679299.00100

CNN Indonesia. (2018, September 26). BlakblakanGubernurAniesSoalPencabutanIzinPulauReklamasi I Exclusive Interview [Video]. YouTube. https://www.youtube.com/watch?v=VCyRHYsWcLc

Colven, Emma. (2017). Understanding the Allure of Big Infrastructure: Jakarta's Great Garuda Sea Wall Project. Water Alternatives 10 (2), 250-264. http://www.wateralternatives.org/index.php/alldoc/articles/vol10/v10issue2/354-a10-2-4/file 
Damarjati, Danu. (2018, June 13). KoalisiSelamatkanTeluk Jakarta KecamPergub BKP ReklamasiAnies. DetikNews. https://news.detik.com/berita/d-4067111/koalisiselamatkan-teluk-jakarta-kecam-pergub-bkp-reklamasi-anies

Daugbjerg, Carsten and Marsh, David. (1998). Explaining Policy Outcomes: Integrating the Policy Network Approach with Macro-Level and Micro-Level Analysis. In David Marsh (Eds.), Comparing Policy Network, (pp. 52-74) Open University Press.

Dowding, Keith. (1995). Model or Metaphor? A Critical Review of the Policy Network Approach. Political Studies 43 (1), 136-158. https://doi.org/10.1111/j.14679248.1995.tb01705.x

Dowding, K. (1995). Model or Metaphor? A Critical Review of the Policy Network Approach. Political Studies, 43(1), 136-158. https://doi.org/10.1111/j.14679248.1995.tb01705.x

Elliott, H., \& Squire, C. (2017). Narratives across Media as Ways of Knowing. Forum Qualitative Sozialforschung/ Forum: Qualitative Social Research 18 (1), 1-5. http:/ / dx.doi.org/10.17169/fqs-18.1.2767

Fadhilah, UmiNur. (2016, July 27). PengamatSebut Rizal RamliDidepakkarenaTerkaitReklamasi. Republika. https://www.republika.co.id/ berita/nasional/politik/16/07/27/oayopi366-pengamat-sebut-rizal-ramli-didepakkarena-terkait-reklamasi

Fadhil, Haris. (2016, November 9). Anies-Sandi Janji Akan HentikanReklamasiTeluk Jakarta. Detiknews. https://news.detik.com/berita/d-3341506/anies-sandi-janjiakan-hentikan-reklamasi-teluk-jakarta

Gabrillin, Abba. (2016, April 10). MenteriSiti: ReklamasiTeluk Jakarta HarusPerbaikiKajianDampakLingkungan. Kompas.com. https:// n a sional.kompas.com.com/read/2016/10/04/15470171/ menteri.siti.reklamasi.teluk.jakarta.harus.perbaiki.kajian.dampak.lingkungan

George, Alexander L. and Bennett, Andrew. (2005). Case Studies and Theory Development in the Social Sciences. MIT Press.

Hakim, Catherine. (2000). Research Design. Routledge.

Harahap, Riza. (2016, July 28). Peneliti: Pencopotan Rizal RamlikagetkanPublik. Antaranews. https://www.antaranews.com/berita/575454/peneliti-pencopotanrizal-ramli-kagetkan-publik

Haas, Peter M. (1992). Introduction: Epistemic Communities and International Policy Coordination. International Organization 46 (1), 1-35. https://www.jstor.org/stable/ 2706951

Hay, Colin. (1998). The Tangled Webs We Weave: The Discourse, Strategy and Practice of Networking. In David Marsh (Eds.), Comparing Policy Network, (pp. 33-51) Open University Press. 
Henaldi, Widi. (2018, October 9). HentikanReklamasiBernilaiRatusanTriliun, AniesSindir Cara KerjaAhok: Pakai Cara Koboy. Tribunnews. https://www.tribunnews.com/ nasional/2018/10/09/hentikan-reklamasi-bernilai-ratusan-triliun-anies-sindir-carakerja-ahok-pakai-cara-koboy

Hidayat, Avit. (2016, April 15). Menteri Susi HentikanProyekReklamasiTeluk Jakarta. Tempo.co. https://nasional.tempo.co/read/762963/menteri-susi-hentikan-proyekreklamasi-teluk-jakarta/full\&view $=$ ok

Hidayat, Avit. (2016, September 10). BeginiKritikWalhikepadaMenteriLuhuttentangReklamasi. Tempo.co. https:// metro.tempo.co/read/803308/ begini-kritik-walhi-kepada-menteri-luhut-tentangreklamasi $/$ full\&view $=$ ok

Himawan, Adhitya. (2016, October 22). InilahSejarahPanjangMegaproyekReklamasiTeluk Jakarta. Suara.com. https:// www.suara.com/bisnis/2016/10/22/150106/inilah-sejarah-panjang-megaproyekreklamasi-teluk-jakarta

Huda, Mas Alamil. (2016, October 20). Pak AniesJanganGusur Kamal MuaradanHentikanReklamasi. Republika. https:/ / nasional.republika.co.id/berita/ ofbs3a382/ pak-anies-jangan-gusur-kamal-muara-dan-hentikan-reklamasi

IPB University. (2018, July 16). The existence of Jakarta Bay is Important to Maintain. https://ipb.ac.id/news/index/2018/07/the-existence-of-jakarta-bay-is-important-tomaintain/8e835ec011ec0edfa90e016390dafd0e

Irianto, HariEko, Hartati, Sri Turni, \&LilisSadiyah. (2017). Fisheries and Environmental Impacts in the Great Jakarta Bay Ecosystem. Indonesian Fisheries Research Journal 23 (2), 69-78. http://dx.doi.org/10.15578/ifrj.23.2.2017.69-78

Junita, Nancy. (2017, October 24). ReklamasiTeluk Jakarta: Anies-Sandi vs Luhut." Jakarta Bisnis. https://jakarta.bisnis.com/read/20171024/77/702416/reklamasi-telukjakarta-anies-sandi-vs-luhut

Kahler, M. (Ed.). (2009). Networked politics: Agency, Power, and Governance. Cornell University Press.

Karim, Muhamad. N.d.Pokok-PokokPikiranReklamasiTeluk Jakarta Dan PengelolaanPesisir Dan Laut Indonesia. (pp. 1- 4). https://acch.kpk.go.id/images/ ragam/makalah/pdf/reklamasi/Pokok-pikiran-reklamasi-teluk-jakarta-danpengelolaan-pesisir-dan-laut-indonesia-muhamad-karim.pdf

KemaritimandanInvestasi. (2016, April 18). Rizal RamliPastikan Moratorium ProyekReklamasi. https:/ / maritim.go.id/rizal-ramli-pastikan-moratorium-proyekreklamasi/

KemaritimandanInvestasi. (2016, April 18). Rizal Ramli: ProyekReklamasiMemangBeresiko. https://maritim.go.id/rizal-ramli-proyekreklamasi-memang-beresiko/ 
KemaritimandanInvestasi. (2016, Mei 4). Rizal RamliDengarAspirasiNelayanTeluk Jakarta.". https:/ / maritim.go.id/rizal-ramli-dengar-aspirasi-nelayan-teluk-jakarta-2/ KementerianLingkunganHidupdanKehutanan (KLHK). (2017). ReklamasiPantai Utara Jakarta. KementerianLingkunganHidupdanKehutanan.

Klijn, Erik Hans, Koppenjan, Joop\&Termeer, Katrien. (1995). Managing Networks in the Public Sector: A Theoretical Study of Management Strategies in Policy Networks. Public Administration 73 (3), 437-454. https:// doi.org/10.1111/j.1467-9299.1995.tb00837.x

KoalisiPakarInterdisiplin. (2017). SelamatkanTeluk Jakarta. Rujak Center for Urban Studies. https:/ / www.bantuanhukum.or.id/web/wp-content/uploads / 2017/10/ Makalah-Kebijakan-Selamatkan-Teluk-Jakarta.pdf

Kompas.com TV. (2016, April 30). Ahok: SecaraHukum, ReklamasiTidakBisaDihentikan [Video]. YouTube. https://www.youtube.com/watch?v=10OSSzJXoGw

Kisby, Ben. (2007). Analysing Policy Networks: Towards an ideational approach. Policy Studies 28 (1), 71-90. https://doi.org/10.1080/01442870601121502

Kuwado, Fabian Januarius. (2017, July 11). LuhutIngatkanAniesBaswedanWajibLanjutkanReklamasi. Kompas.com. https:// n a sional.kompas.com .com / read/2017/07/11/21065841/ luhut.ingatkan.anies.baswedan.wajib.lanjutkan.reklamasi

LembagaBantuanHukum (LBH) Jakarta. (2019, September 10). MemaknaiReklamasiTeluk Jakarta. https://www.bantuanhukum.or.id/web/ memahami-proyek-reklamasitelukjakarta/

Nailufar, Nibras Nada. (2018, November 27). PerkembanganPulauReklamasi di TanganGubernurAnies. Kompas.com. https://megapolitan.kompas.com.com/read/ 2018/11/27/09093061/perkembangan-pulau-reklamasi-di-tangan-gubernuranies?page $=$ all

Mahdi, Imam. (2017) ReklamasiTeluk Jakarta: SebuahPrespektifKekuasaanDalamEkonomiPolitik. JurnalTransformasi Global 4 (1), 3845. https://transformasiglobal.ub.ac.id/index.php/trans/article/view/66/56

Marsh, David. (1998). The Development Of The Policy Network Approach. In David Marsh (Eds.), Comparing Policy Network, (pp. 3-20) Open University Press.

Marsh, David. (1998). The Utility and Future of Policy Network Analysis. In David Marsh (Eds.), Comparing Policy Network, (pp. 185-198) Open University Press.

Marsh, David \& Rhodes, R. A. W. (1992). Policy Communities and Issue Networks. In David Marsh and R.A. W. Rhodes (Eds.), Policy Networks in British Government, (pp. 249-268) Clarendon Press.

Marsh, David \& Smith, Martin J. (2000). Understanding Policy Networks: towards a Dialectical Approach. Political Studies, 48 (1), 4-21. https://doi.org/10.1111/14679248.00247 
Marsh, David \& Smith, Martin J. (2001). There Is More Than One Way To Do Political Science: On Different Ways To Study Policy Networks. Political studies, 49 (3), 528541. https://doi.org/10.1111\%2F1467-9248.00325

Metrotvnews. (2018, February 21). MenkoLuhut: ReklamasiKini Ada di TanganPemprov DKI. [Video]. YouTube. https://www.youtube.com/watch?v=q-uM3_Pr73Y

Metrotvenew. (2017, April 12). Ahok Vs AniesDebatSoalReklamasi [Video]. YouTube. https:/ / www.youtube.com/watch?v=YOtUIoV-FDU

Mutia, ElokFaiqotul\&Asteria, Donna. (2008). Jakarta Bay Reclamation Policy: An Analysis of Political Ecology. E3S Web of Conferences 52 (00014), 1-8.https://doi.org/10.1051/ e3sconf / 20185200014

Mutia, ElokFaiqotul, Herdiansyah, Herdis\&Haryanto, Joko Tri. (2019). Conflict of Jakarta Bay Reclamation: Government Knowledge and Respond. Journal of Physics: Conference Series (1363), 1-6. https://iopscience.iop.org/article/10.1088/1742-6596/ 1363/1/012099

Peterson, J. (2003). Policy Networks. ReihePolitikwissenschaft/ Political Science Series 90, 129. https://www.ihs.ac.at/publications/pol/pw_90.pdf

Pradewo, Bintang. (2018, September 26). Akhirnya, AniesResmiHentikanPengerjaanReklamasi 13 Pulau. Jawa Pos. https:// www.jawapos.com/jpg-today/26/09/2018/akhirnya-anies-resmi-hentikanpengerjaan-reklamasi-13-pulau/

Pratiwi, Priska Sari. (2017, October 18). MenagihJanjiAnies-Sandi HentikanReklamasiTeluk Jakarta. CNN Indonesia. https://www.cnnindonesia.com/nasional/2017101808512020-249171/menagih-janji-anies-sandi-hentikan-reklamasi-teluk-jakarta

PT. Kapuk Naga Indah. (2012). AnalisisDampakLingkungan (ANDAL) ReklamasiPantaiKapuk Naga Indah. Jakarta. https:/ /lingkunganhidup.jakarta.go.id/ wp-content/uploads/2017/05/ANDAL\%20PULAU\%20CDE.pdf

Putera, AndriDonnal. (2017, October 10). JanjiAnies-Sandi HentikanReklamasidanPerkembanganTerkini. Kompas.com. https:// megapolitan.kompas.com.com/read/2017/10/10/15281411/janji-anies-sandihentikan-reklamasi-dan-perkembangan-terkini?page=all

Rahmawati, Restu\&Firman. (2019). ReklamasiTeluk Jakarta DitinjaudariPerspektifEkofeminisme. ARISTO 7 (1), 46-63. http://dx.doi.org/ 10.24269/ars.v7i1.1303

Ramadhan, A., Firdaus, M., Wijaya, R. A., \&Muliawan, I. (2016). EstimasiKerugianNelayandanPembudidayaIkanAkibatReklamasi di Teluk Jakarta. JurnalSosialEkonomiKelautandanPerikanan 11(1), 1-11.

Redaksi. (2017, December 8). SoalReklamasi, NelayanTerusLakukan 'Perlawanan' kePemprov DKI. Edunews. http://www.edunews.id/news/soal-reklamasi-nelayanterus-lakukan-perlawanan-ke-pemprov-dki 
Rhodes, R.A.W. (1997). Understanding Governance: Policy Networks, Governance, Reflexivity and Accountability. Open University Press.

Rhodes, R.A.W. (2007). Understanding Governance: Ten Years On. Organization Studies 28 (8), 1-22. https://doi.org/10.1177\%2F0170840607076586

Richardson, Jeremy. (2000). Government, Interest Groups and Policy Change. Political Studies 48 (5), 1006-25. https:// doi.org/10.1111/1467-9248.00292

Rudianto, AndiGustiTantu. (2014). An analysis of coastal land conflict in the North of Jakarta coastal area: A general algebraic modelling system approach. Journal of Coastal Conservation 18 (1), 69-74. https:// doi.org/10.1007/s11852-013-0298-4

Salim, Wilmar, Bettinger, Keith, \& Micah Fisher. (2019). Maladaptation on the Waterfront: Jakarta's Growth Coalition and the Great Garuda. Environment and Urbanization ASIA 10 (1), 63-80. https:/ / doi.org/10.1177\%2F0975425318821809

Sari, Nursita. (2018, September 26). Gubernur DKI HentikanProyekReklamasi, Izin 13 PulauDicabut. Kompas.com. https://megapolitan.kompas.com.com/read/2018/09/ 26/17081541/gubernur-dki-hentikan-proyek-reklamasi-izin-13-pulau-dicabut

Setiaji, Hidayat. (2019, June 17). JejakSuramReklamasi Jakarta: Dari PolitikSampaiKasusSuap. CNBC Indonesia. https://www.cnbcindonesia.com/news/ 20190617122502-4-78733/jejak-suram-reklamasi-jakarta-dari-politik-sampai-kasussuap

Simbolon, Christian Dior. (2016, April 25). SK Moratorium ReklamasiTeluk Jakarta HakGubernur DKI. Media Indonesia. https://mediaindonesia.com/read/detail/ 42198-sk-moratorium-reklamasi-teluk-jakarta-hak-gubernur-dki

Skogstad, Grace. (2005, June 2). Policy Networks and Policy Communities: Conceptual Evolution and Governing Realities. (First Draf, Workshop on "Canada's Contribution to Comparative Theorizing"). Annual Meeting of the Canadian Political Science Association University of Western Ontario, Ontario. https://www.researchgate.net/ publication/228811682

Supartono, J. Haluan, M.F.A. Sondita\&Manuwoto. (2015). Jakarta North Coast Development Impact on Fishery Activities. Asian Journal of Scientific Research, 9 (1), 14-23. http://dx.doi.org/10.3923/ajsr.2016.13.23

Tim. (2018, September 30). Menteri LHK AkuiSudah Bahas ReklamasidenganAnies. CNN Indonesia. https://www.cnnindonesia.com/nasional/20180930181655-20-334469/ menteri-lhk-akui-sudah-bahas-reklamasi-dengan-anies

Utomo, Citra Pulandi. (2017, November 13). ReklamasiTeluk Jakarta, AncamanatauRestorasiLingkungan? Kumparan. https://kumparan.com/citrapulandi-utomo/reklamasi-teluk-jakarta-ancaman-atau-restorasi-lingkungan1510561112007

Velarosdela, RindiNuris. (2018, December 17). PerjalananPanjangReklamasiTeluk Jakarta, dariSoehartohinggaAnies. Kompas.com. https://megapolitan.kompas.com/read/ 
2018/12/17/12524161/ perjalanan-panjang-reklamasi-teluk-jakarta-dari-soehartohingga-anies? page $=$ all

Y Adharani et al. (2019). Jakarta Bay Reclamation: The Challenge between Policy, Environmental and Social Impacts. IOP Conf. Series: Earth and Environmental Science, 306: 1-8. 10.1088/1755-1315/306/1/012025

Yi, H., \&Scholz, J. T. (2016). Policy Networks in Complex Governance Subsystems: Observing and Comparing Hyperlink, Media, and Partnership Networks. Policy Studies Journal, 44 (3), 248-279.

Yin, Robert K. (2018). Case Study Research and Applications: Design and Methods, (6th Ed.). Sage.

Yin, Robert K. (2011). Qualitative research from Start to finish. The Guilford Press.

Yin, Robert K. (2009). How to Do Better Case Studies (With Illustrations from 20 Exemplary Case Studies). In Leonard Bickman and Debra J. Rog (eds.), The SAGE handbook of applied social research methods, (pp. 254-282) SAGE Publications. 